\title{
Oral Glutamine Is Superior Than Oral Glucose to Promote Glycemia Recovery in Mice Submitted to Insulin-Induced Hypoglycemia
}

\author{
Amanda Nunes Santiago, ${ }^{1}$ Vilma Aparecida Ferreira de Godoi-Gazola, ${ }^{2}$ \\ Mariana Fachin Milani, ${ }^{2}$ Vanessa Cristina de Campos, ${ }^{2}$ Vanessa Rodrigues Vilela, ${ }^{1}$ \\ Maria Montserrat Diaz Pedrosa, ${ }^{2}$ and Roberto Barbosa Bazotte ${ }^{1}$ \\ ${ }^{1}$ Department of Pharmacology and Therapeutics, State University of Maringá, 87020-900 Maringá, PR, Brazil \\ ${ }^{2}$ Department of Physiological Sciences, State University of Maringá, 87020-900 Maringá, PR, Brazil
}

Correspondence should be addressed to Roberto Barbosa Bazotte; rbbazotte@uem.br

Received 23 March 2013; Revised 19 June 2013; Accepted 24 July 2013

Academic Editor: Dariush Elahi

Copyright (C) 2013 Amanda Nunes Santiago et al. This is an open access article distributed under the Creative Commons Attribution License, which permits unrestricted use, distribution, and reproduction in any medium, provided the original work is properly cited.

The effect of the oral administration of blood glucose precursors on glycemia recovery and liver glucose production in fasted mice subjected to insulin-induced hypoglycemia (IIH) was investigated. IIH was obtained with increasing doses (from 0.5 to $2.0 \mathrm{U} \cdot \mathrm{kg}^{-1}$ ) of intraperitoneal regular insulin where glycemia was evaluated from 0 to $300 \mathrm{~min}$ after insulin injection. The dose of $1.0 \mathrm{U} \cdot \mathrm{kg}^{-1}$ showed the best results, that is, a clear glycemia recovery phase without convulsions or deaths. Thus, this dose was used in all experiments. Afterwards, mice submitted to IIH received orally by gavage: saline (control group), glucose (100 mg. $\left.\mathrm{kg}^{-1}\right)$, glycerol $\left(100 \mathrm{mg} \cdot \mathrm{kg}^{-1}\right)$, lactate $\left(100 \mathrm{mg} \cdot \mathrm{kg}^{-1}\right)$, alanine $\left(100 \mathrm{mg} \cdot \mathrm{kg}^{-1}\right)$, or glutamine $\left(100 \mathrm{mg} \cdot \mathrm{kg}^{-1}\right)$. It was observed that glutamine was more effective in promoting glycemia recovery if compared with glucose, lactate, glycerol, or alanine. In agreement with these results, the best performance in terms of liver glucose production was obtained when glutamine was used as glucose precursors. These results open perspectives for clinical studies to investigate the impact of oral administration of gluconeogenic amino acids to promote glycemia recovery during hypoglycemia.

\section{Introduction}

Diabetes is a chronic disease that requires careful monitoring and control. Without proper management it can lead to chronic hyperglycemia associated with long-term complications that include nephropathy, neuropathy, retinopathy, and several other disorders. It must be emphasized that all these complications could be prevented by intensive insulin therapy. However, intensive insulin therapy, essential for type 1 diabetic patients and some of those with type 2, has insulininduced hypoglycemia (IIH) as its major adverse effect $[1,2]$. Moreover, IIH can trigger significant neurologic alterations, neuronal death, coma, and death $[3,4]$.

To better understand the mechanisms of IIH we developed an experimental model in which hypoglycemia was obtained by an intraperitoneal injection of a pharmacological dose of regular insulin in nondiabetic Wistar rats. This animal model that has been used by our research group since 1994 [5] is suitable to investigate the metabolic changes induced by IIH [6-12].

Thus, by using this rat model we obtained considerable progress in the elucidation of the mechanisms of IIH. For example, despite the paradigm that insulin inhibits hepatic gluconeogenesis, our previous studies in rats suggest that the counterregulatory mechanisms can surpass the inhibitory effects of insulin on liver gluconeogenesis [7-12]. In agreement with our studies, other investigations demonstrated that the administration of gluconeogenic precursors such as alanine [13], lactate [14], and pyruvate [15] during IIH decreased the risk of hypoglycemia and/or promoted glycemia recovery.

Considering that the Swiss mouse is a suitable animal model for studies of regulation of glycemia and liver 
metabolism [16-19], in this study we evaluated the effect of the oral administration of hepatic glucose precursors on the glycemia and liver glucose production in mice subjected to IIH.

\section{Materials and Methods}

\subsection{General Experimental Procedures}

2.1.1. Chemicals. Alanine and glutamine were obtained from ICN Biochemicals (Costa Mesa, CA, USA). NAD, NADH, and lactate dehydrogenase were obtained from Sigma Chemical Co. (St. Louis, USA). Regular insulin (Novolin) was purchased from Novo Nordisk (Brazil). All other reagents were of the the best available grade (98-99.8\% purity).

2.1.2. Animals. Adult male Swiss mice (Mus musculus) weighting 20-30 g were used. The animals had free access to water and food (Nuvilab rodent chow) and were kept under constant temperature $\left(23 \pm 1^{\circ} \mathrm{C}\right)$ until the day before the experiment. At this day the food was removed at 5:00 p.m. All experiments were done after an overnight fasting (5:00 p.m7:00 a.m), so at the moment of the experiments the animals were at a $14 \mathrm{hr}$ fasting.

All experiments were approved by the Committee of Ethics in Animal Experimentation (079-PRO 051.2011).

2.2. Determination of the Glycemic Curve. The animals were divided into six groups according to the dose $\left(\mathrm{U} \cdot \mathrm{kg}^{-1}\right.$ body weight) of intraperitoneal (ip) regular insulin (Novolin) that was given: 0.0 vehicle $(n=4), 0.1(n=4), 0.5(n=4), 1.0$ $(n=9), 1.5(n=4)$, and $2.0(n=4)$. Seven blood samples were collected from the tail of each animal 0, 30, 60, 120, 180, 240, and $300 \mathrm{~min}$ after the ip injection of insulin or vehicle. The glycemia $\left(\mathrm{mg} \cdot \mathrm{dL}^{-1}\right)$ was determined with the aid of a home glucometer (Optium Xceed).

2.3. Evaluation of Glycemia after Oral Administration of Gluconeogenic Precursors in Mice Subjected to IIH. After insulin administration $\left(1.0 \mathrm{U} \cdot \mathrm{kg}^{-1}\right)$, the animals were divided into six groups: saline ( $n=38$, i.e., $3-7$ mice for each time), glucose $100 \mathrm{mg} \cdot \mathrm{kg}^{-1}$ ( $n=37$, i.e., 3-6 mice for each time), glycerol $100 \mathrm{mg} \cdot \mathrm{kg}^{-1}(n=21$, i.e., $2-3$ mice for each time), lactate $100 \mathrm{mg} \cdot \mathrm{kg}^{-1}$ ( $n=17$, i.e., $2-3$ mice for each time), alanine $100 \mathrm{mg} \cdot \mathrm{kg}^{-1}(n=21$, i.e., $2-3$ mice for each time), or glutamine $100 \mathrm{mg} \cdot \mathrm{kg}^{-1}$ ( $n=22$, i.e., 2-3 mice for each time). The gluconeogenic precursors, as well as saline and glucose (as control groups), were given orally through gavage $15 \mathrm{~min}$ after the insulin injection. The glycemia was determined with a home glucometer (Optium Xceed) from the tail blood at 0 , $15,30,60,120,180,240$, and $300 \mathrm{~min}$ after ip insulin injection.

2.4. Liver Perfusion Experiments. In another set of the experiments, the livers were isolated and perfused in situ. For this purpose, the mice received ip saline or ip regular insulin $\left(1.0 \mathrm{U} \cdot \mathrm{kg}^{-1}\right)$, respectively, and $180 \mathrm{~min}$ after insulin (IIH group) or saline (NORMO group) injection they were

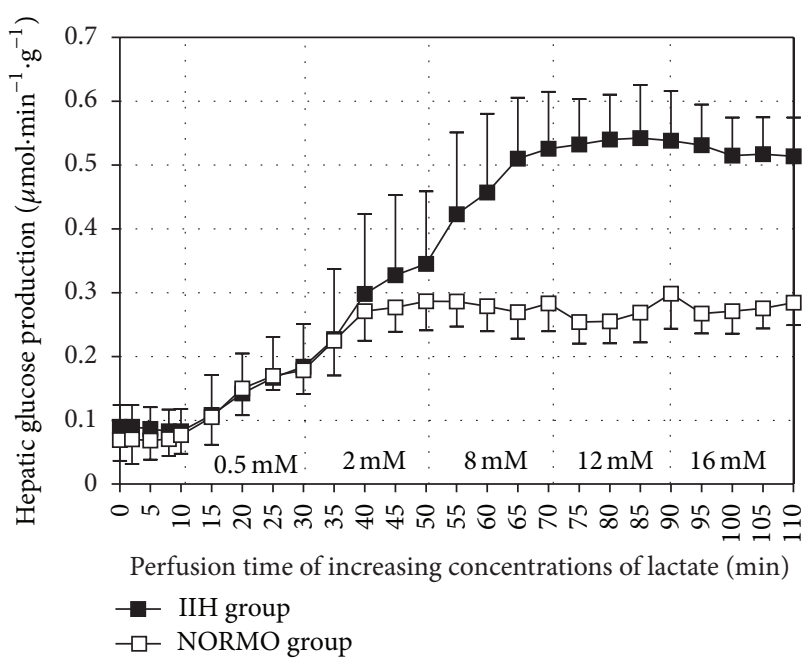

FIgURE 1: Demonstrative experiments $(n=3-4)$ of glucose production from increasing concentrations of lactate in perfused liver of fasted mice that received intraperitoneal injection of insulin (IIH group, --) or saline (NORMO group, $\square-$ ). The effluent fluid was collected at $5 \mathrm{~min}$ intervals and analyzed for glucose. The areas under curve (the increment of glucose production between 10 and $110 \mathrm{~min}$ ) of NORMO and IIH group were $39.51 \pm 0.19$ and $24.96 \pm 0.09$, respectively.

anesthetized (ketamine $60 \mathrm{mg} \cdot \mathrm{kg}^{-1}$ and xylazine $12 \mathrm{mg} \cdot \mathrm{kg}^{-1}$, ip). Hypoglycemia was confirmed by the glycemia from tail blood just before anesthesia.

The perfusion fluid, the Krebs-Henseleit buffer (KHB), $\mathrm{pH} 7.4,37^{\circ} \mathrm{C}$, and saturated with a $95 \%: 5 \% \mathrm{O}_{2}: \mathrm{CO}_{2}$ mixture, was introduced $\left(4 \mathrm{~mL} \cdot \mathrm{min}^{-1} \cdot \mathrm{g}^{-1}\right.$ of liver) through a cannula inserted into the portal vein. The composition of the KHB buffer was $115 \mathrm{mM} \mathrm{NaCl}, 25 \mathrm{mM} \mathrm{NaHCO}, 5.8 \mathrm{mM} \mathrm{KCl}$, $1.2 \mathrm{mM} \mathrm{Na}_{2} \mathrm{SO}_{4}, 1.18 \mathrm{mM} \mathrm{MgCl}_{2}, 1.2 \mathrm{mM} \mathrm{NaH}_{2} \mathrm{PO}_{4}$, and $2.5 \mathrm{mM} \mathrm{CaCl}_{2}$. The gluconeogenic precursors glycerol $(n=$ 26 for NORMO group and $n=29$ for HII group, i.e., $3-5$ and 3-6 mice, resp., for each concentration), lactate $(n=33$ for NORMO group and $n=26$ for HII group, i.e., $3-8$ and 3-6 mice, resp., for each concentration), alanine ( $n=32$ for NORMO group and $n=37$ for HII group i.e., 3-7 and 3-8 mice, resp., for each concentration), or glutamine ( $n=25$ for NORMO group and $n=35$ for HII group, i.e., and 3-6 mice, resp., for each concentration) were dissolved in the perfusion fluid at increasing concentrations of $0.5,1.0,2.0,4.0,8.0$, 12.0 , and $16.0 \mathrm{mM}$. The effluent perfusate from the liver was collected at intervals of $5 \mathrm{~min}$ through a cannula inserted into the inferior vena cava. At the end of the experiment, the liver was removed and weighted so that the liver production of glucose, lactate [20], pyruvate [21], and urea [22] can be expressed by gram of liver $\left(\mu \mathrm{mol} \cdot \mathrm{min}^{-1} \cdot \mathrm{g}^{-1}\right)$.

Figure 1 summarizes a demonstrative experiments and the calculation of the area under curves. Thus, after a preinfusion period of $10 \mathrm{~min}$ (basal glucose production), increasing concentrations of lactate were dissolved in the perfusion fluid and infused from 10 to $110 \mathrm{~min}$. The samples of the effluent fluid were collected at 5 min intervals, and the concentration of glucose was measured. The difference 
TABLE 1: Liver production of pyruvate from increasing concentrations $(\mathrm{mM})$ of lactate and liver production of pyruvate or lactate from increasing concentrations $(\mathrm{mM})$ of alanine in fasted mice. The animals were subjected to in situ liver perfusion 180 min after an intraperitoneal injection of regular insulin (1.0 U $\cdot \mathrm{kg}^{-1}$, IIH group) or saline (NORMO group). The areas under curve (AUCs), that is, the increment of pyruvate and L-lactate production between 10 and 110 min were calculated as described in Section 2.

\begin{tabular}{|c|c|c|c|c|}
\hline \multirow{3}{*}{ Glucose precursor } & \multicolumn{4}{|c|}{ AUC of liver production of pyruvate and lactate $\left(\mu \mathrm{mol} \cdot \mathrm{g}^{-1}\right)$} \\
\hline & \multicolumn{2}{|c|}{ Pyruvate } & \multicolumn{2}{|c|}{ Lactate group HII } \\
\hline & NORMO group & IIH group & NORMO group & IIH group \\
\hline \multicolumn{5}{|l|}{ Lactate $\mathrm{mM}$} \\
\hline 0.5 & $0.04 \pm 0.01$ & $0.04 \pm 0.01$ & $\mathrm{Nd}$ & $\mathrm{Nd}$ \\
\hline 1.0 & $0.04 \pm 0.01$ & $0.05 \pm 0.02$ & $\mathrm{Nd}$ & $\mathrm{Nd}$ \\
\hline 2.0 & $0.13 \pm 0.02$ & $0.18 \pm 0.06$ & $\mathrm{Nd}$ & $\mathrm{Nd}$ \\
\hline 4.0 & $0.34 \pm 0.08$ & $0.31 \pm 0.06$ & $\mathrm{Nd}$ & $\mathrm{Nd}$ \\
\hline 8.0 & $0.74 \pm 0.08$ & $0.85 \pm 0.09$ & $\mathrm{Nd}$ & $\mathrm{Nd}$ \\
\hline 12.0 & $1.23 \pm 0.13$ & $1.25 \pm 0.14$ & $\mathrm{Nd}$ & $\mathrm{Nd}$ \\
\hline 16.0 & $1.58 \pm 0.15$ & $1.53 \pm 0.06$ & $\mathrm{Nd}$ & $\mathrm{Nd}$ \\
\hline \multicolumn{5}{|l|}{ Alanine mM } \\
\hline 0.5 & $0.02 \pm 0.01$ & $0.02 \pm 0.01$ & $0.05 \pm 0.04$ & $0.07 \pm 0.02$ \\
\hline 1.0 & $0.03 \pm 0.01$ & $0.02 \pm 0.01$ & $0.14 \pm 0.04$ & $0.11 \pm 0.03$ \\
\hline 2.0 & $0.07 \pm 0.02$ & $0.06 \pm 0.02$ & $0.23 \pm 0.05$ & $0.18 \pm 0.05$ \\
\hline 4.0 & $0.12 \pm 0.04$ & $0.07 \pm 0.01$ & $0.44 \pm 0.04$ & $0.28 \pm 0.06$ \\
\hline 8.0 & $0.33 \pm 0.10$ & $0.48 \pm 0.13$ & $0.60 \pm 0.05$ & $0.42 \pm 0.02$ \\
\hline 12.0 & $0.26 \pm 0.08$ & $0.85 \pm 0.14^{*}$ & $0.65 \pm 0.08$ & $0.84 \pm 0.05^{*}$ \\
\hline 16.0 & $0.18 \pm 0.09$ & $1.16 \pm 0.09^{*}$ & $0.63 \pm 0.06$ & $1.16 \pm 0.11^{*}$ \\
\hline
\end{tabular}

Values of the area under curve $\left(\mu \mathrm{mol} \cdot \mathrm{g}^{-1}\right)$ are represented as mean \pm standard deviation of $6-8$ perfusion experiments. ${ }^{*} P<0.05 \mathrm{NORMO}$ versus IIH. Nd: not determined.

in the liver glucose production (LGP) during the infusion period of each concentration of lactate and the basal LGP was used to calculate the AUCs, expressed as $\mu \mathrm{mol} \cdot \mathrm{g}^{-1}$. The AUCs presented in Figure 4 and Table 1 were obtained from similar experiments.

2.5. Statistical Procedure. The results were expressed as mean \pm standard deviation (SD) of 6-8 experiments. The level of significance adopted was 5\% $(P<0.05)$. The means were compared through unpaired Student's $t$-test or ANOVA. The calculations and statistical analyses were carried out using GraphPad Prism version 5.0.

\section{Results}

3.1. Determination of the Glycemic Curve. The group that received saline showed decreased glycemia $(P<0.05)$ between the initial time $(0 \mathrm{~min})$ and 240 or $300 \mathrm{~min}$ after saline injection. Moreover, we observed decrease $(P<0.05)$ of glycemia between 60 and $300 \mathrm{~min}$ after saline injection (Figure 2).

Insulin administration $\left(0.1 \mathrm{U} \cdot \mathrm{kg}^{-1}\right)$ decreases glycemia $(P<0.05)$ between $0 \mathrm{~min}$ and $30 \mathrm{~min}$ (Figure 2). Insulin administration $\left(0.5 \mathrm{U} \cdot \mathrm{kg}^{-1}\right)$ also promotes the decrease $(P<$ 0.05 ) of the glycemia when 0 min was compared to 30,60 , 120 , and $180 \mathrm{~min}$. In addition, an increase $(P<0.05)$ of the glycemia between $60 \mathrm{~min}$ and $300 \mathrm{~min}$ after insulin injection was observed (Figure 2).
When the doses of 1.0, 1.5, and $2.0 \mathrm{U} \cdot \mathrm{kg}^{-1}$ of insulin were evaluated, we observed a fall $(P<0.05)$ in the glycemia from $30 \mathrm{~min}$ until $120 \mathrm{~min}$. Additionally, the difference $(P<$ 0.05 ) between $60 \mathrm{~min}$ and $300 \mathrm{~min}$ for these three doses demonstrated glycemia recovery (Figure 2).

Considering that at the dose of $1.5 \mathrm{U} \cdot \mathrm{kg}^{-1}$ or $2.0 \mathrm{U} \cdot \mathrm{kg}^{-1}$ all animals had convulsions and half of them died, the dose of $1.0 \mathrm{U} \cdot \mathrm{kg}^{-1}$ of regular insulin was used in all experiments.

\subsection{Evaluation of the Glycemia after the Oral Administration} of Saline, Glucose, and Gluconeogenic Precursors in Mice Subjected to IIH. The effects of the oral administration of saline, glucose, or gluconeogenic precursors in the rats that received $1.0 \mathrm{U} \cdot \mathrm{kg}^{-1}$ of regular insulin were compared. In all groups there was a decrease $(P<0.05)$ of the glycemia from $15 \mathrm{~min}$ to $60 \mathrm{~min}$, confirming the development of IIH. In addition, all groups showed glycemia recovery $(P<0.05)$. The best performance in terms of glycemia recovery was obtained with glutamine (Figure 3).

Because glycemia recovery started at $180 \mathrm{~min}$ after insulin administration, this time was chosen to evaluate liver gluconeogenesis.

3.3. Liver Glucose Production (LGP) from Increasing Levels of Glycerol, Lactate, Alanine, or Glutamine. The infusion of glycerol, lactate, alanine, and glutamine promoted intensification of LGP in all groups (Figure 4).

The intensification of LGP from glycerol reached its maximum values at the concentration of $4 \mathrm{mM}$ in both 


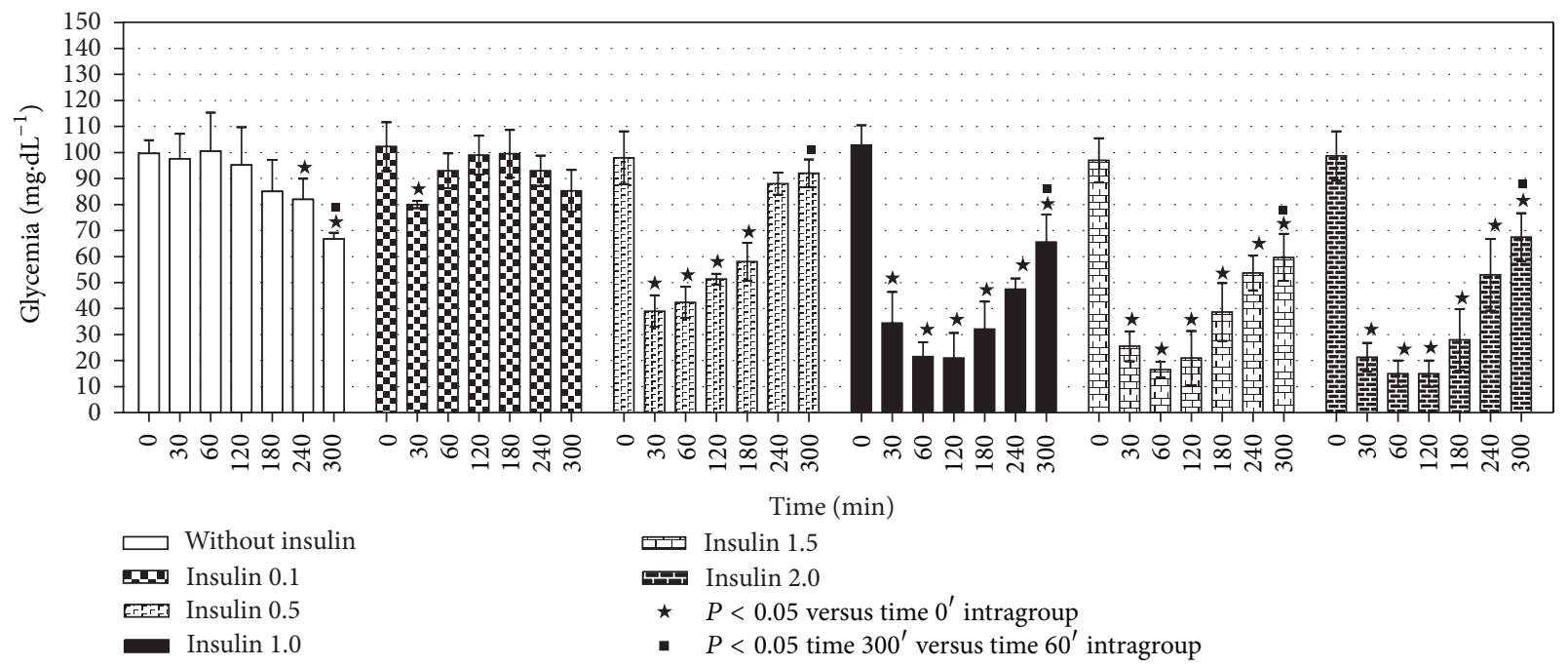

FIGURE 2: Glycemic response as a function of dose and time after intraperitoneal injection of regular insulin in $14 \mathrm{hr}$ fasted mice. In these experiments saline or increasing doses of insulin $\left(0.1,0.5,1.0,1.5\right.$, and $\left.2.0 \mathrm{U} \cdot \mathrm{kg}^{-1}\right)$ were injected. Glycemia was measured $\left(\mathrm{mg} \cdot \mathrm{dL}{ }^{-1}\right) 0,30,60$, $120,180,240$, and $300 \mathrm{~min}$ after insulin injection. Bars are mean \pm standard deviation of $6-8$ experiments. ${ }^{\star} P<0.05$ versus 0 min; ${ }^{\text {" }} P<0.05$ $300 \mathrm{~min}$ versus $60 \mathrm{~min}$.

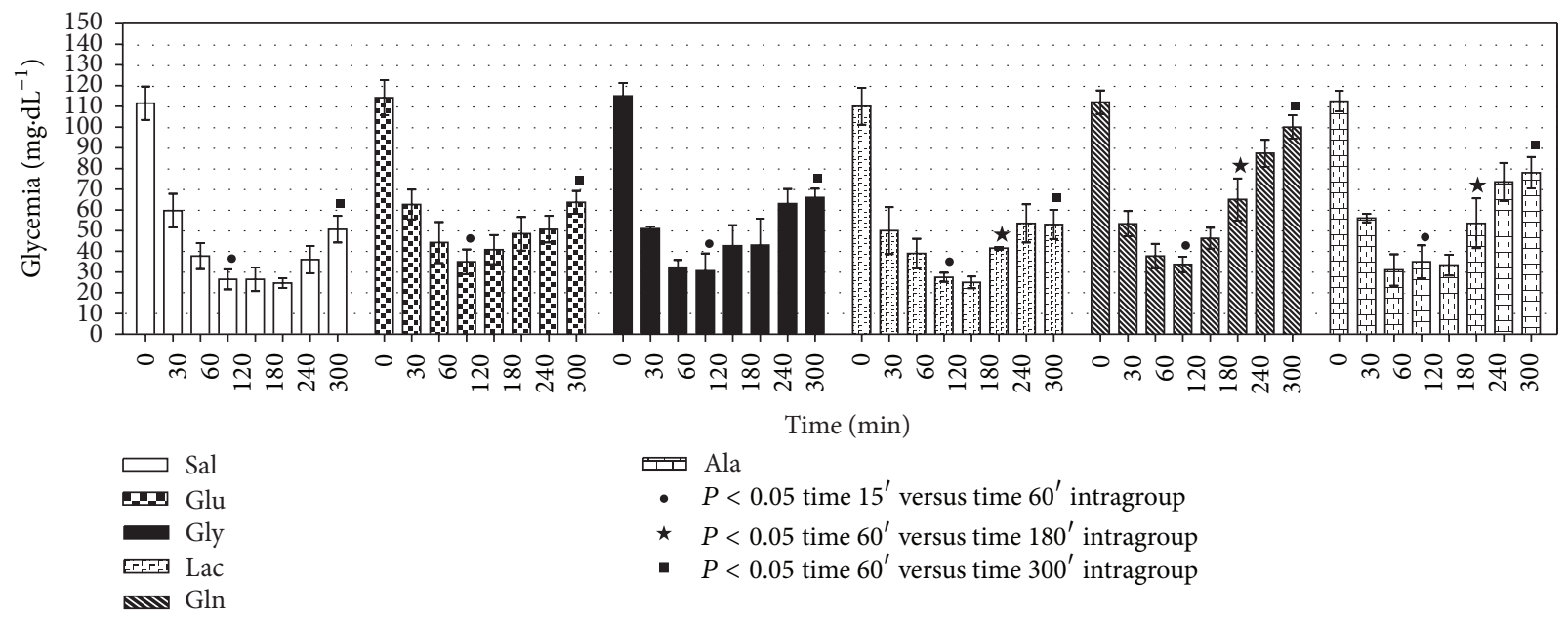

FIGURE 3: Glycemic response after oral administration of saline (Sal), glucose (Glu), glycerol (Gly), lactate (Lac), glutamine (Gln), or alanine (Ala) during insulin-induced hypoglycemia (IIH). IIH was induced in $14 \mathrm{hr}$ fasted mice with an intraperitoneal injection of regular insulin $\left(1.0 \mathrm{U} \cdot \mathrm{kg}^{-1}\right)$. Glycemia $\left(\mathrm{mg} \cdot \mathrm{dL}^{-1}\right)$ was determined $0,15,30,60,120,180,240$, and $300 \mathrm{~min}$ after insulin injection. The oral administration of Sal, Glu $\left(100 \mathrm{mg} \cdot \mathrm{kg}^{-1}\right)$, Gly $\left(100 \mathrm{mg} \cdot \mathrm{kg}^{-1}\right)$, Lac $\left(100 \mathrm{mg} \cdot \mathrm{Kg}^{-1}\right)$, Gln $\left(100 \mathrm{mg} \cdot \mathrm{kg}^{-1}\right)$, and Ala $\left(100 \mathrm{mg} \cdot \mathrm{kg}^{-1}\right)$ was done $15 \mathrm{~min}$ after insulin injection. The bars express the mean \pm standard deviation of $6-8$ experiments. ${ }^{\circ} P<0.0515$ min versus $60 \mathrm{~min},{ }^{\star} P<0.0560$ min versus 180 min, and - $P<0.0560$ min versus $300 \mathrm{~min}$.

groups. However, at concentrations higher than $4 \mathrm{mM}$, there was a progressive return of the LGP to the values observed before glycerol infusion (Figure 4). Additionally, from the concentration of $4 \mathrm{mM}$, the intensification of LGP from lactate was less intense $(P<0.05)$ in the IIH group (Figure 4).

The intensification of LGP from alanine reaches higher values $(P<0.05)$ in the IIH group at the concentrations of 12.0 and $16.0 \mathrm{mM}$ (Figure 4). Furthermore, the intensification of LGP from glutamine reaches higher values $(P<0.05)$ in the IIH group at the concentrations of 1.0, 12.0, and $16.0 \mathrm{mM}$ (Figure 4).

3.4. Liver Production of Pyruvate from Increasing Levels of Lactate and Liver Production of Pyruvate or Lactate from Increasing Levels of Alanine. The production of pyruvate from increasing levels of lactate showed no significant difference (Table 1). On the other hand, pyruvate and lactate production from increasing levels of alanine was higher 


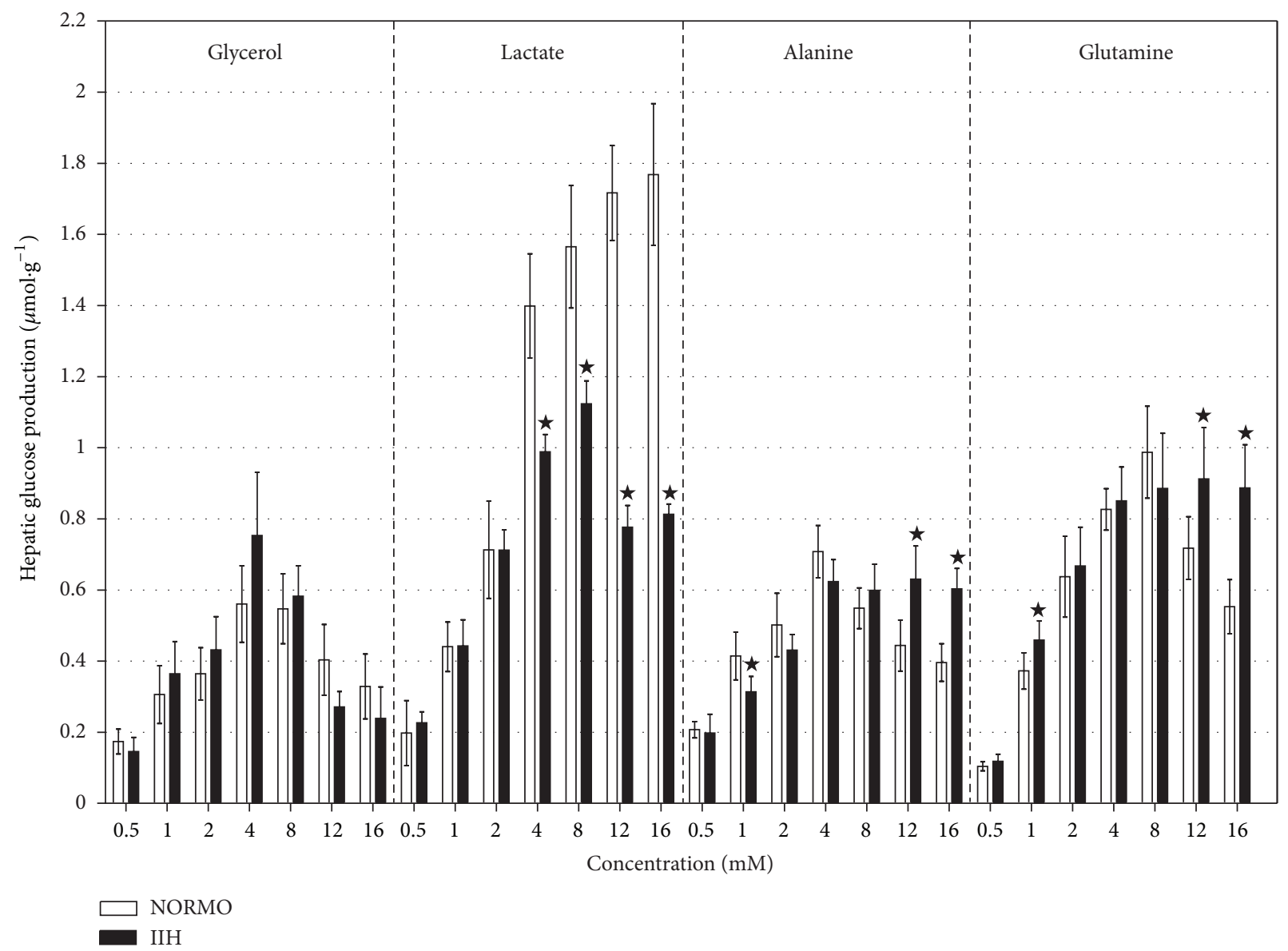

FIGURE 4: Hepatic production of glucose as a function of increasing concentrations of glycerol, lactate, alanine, and glutamine in $14 \mathrm{hr}$ fasted mice. The animals were subjected to in situ liver perfusion $180 \mathrm{~min}$ after an intraperitoneal injection of regular insulin $\left(1.0 \mathrm{U} \cdot \mathrm{kg}^{-1}, \mathrm{IIH}\right.$ group) or saline (NORMO group). The bars express the values of the area under curve $\left(\mu \mathrm{mol} \cdot \mathrm{g}^{-1}\right)$, that is, (the increment of glucose production between 10 and $110 \mathrm{~min})$ as mean \pm standard deviation of 6-8 experiments. ${ }^{\star} P<0.05 \mathrm{IIH}$ versus NORMO.

$(P<0.05)$ than that of the IIH group at the concentrations of 12.0 and $16.0 \mathrm{mM}$ (Table 1$)$.

3.5. Liver Production of Urea from Increasing Levels of Glutamine or Alanine. Similar (IIH versus NORMO) liver urea production from increasing concentrations (from 0.5 to $16.0 \mathrm{mM}$ ) of glutamine (AUC ranged from 0.6 to $10.2 \mu \mathrm{mol}$. $\mathrm{g}^{-1}$ ) or alanine (AUC ranged from 0.4 to $6.6 \mu \mathrm{mol} \cdot \mathrm{g}^{-1}$ ) was observed (results not shown).

\section{Discussion}

Insulin has a potent anabolic effect decreasing the availability of the hepatic glucose precursors [23]. On the other hand, the condition of hyperinsulinemia associated with hypoglycemia leads to the activation of the counterregulatory system with intensification of the release of glucagon and epinephrine [24]. In addition, if hypoglycemia persists for more than two hours, there is an increase in the blood concentration of cortisol and growth hormone and the combination of glucagon, epinephrine, cortisol, and growth hormone could overcome the inhibitory effect of insulin on LGP $[7,25]$. Therefore, even with the inhibitory effect of insulin on gluconeogenesis, the activation of the counterregulatory system allows the liver to produce glucose from noncarbohydrate substrates. However, how these mechanisms work in mice, particularly the LGP and glycemia recovery promoted by the administration of gluconeogenic substrates, should be investigated.

The decreased glycemia (Figure 2) after insulin injection was more intense and prolonged if compared with previous studies in rats [8-12]. Moreover, it was observed that lactate and glycerol were less effective in promoting glycemia recovery compared with the amino acids glutamine and alanine (Figure 3).

Interestingly, oral glutamine promoted better glycemia recovery than glucose (Figure 3), the main antidote used in hypoglycemia [26].

In contrast with rats $[8,10,27]$, oral glutamine showed better glycemia recovery compared with alanine (Figure 3 ). This difference could be attributed to the possibility that in mice the catabolism of glutamine in the enterocytes is lower than in rats [28-30]. 
Since the glycemia recovery depends on LGP, the contribution of glycerol, lactate, alanine, and glutamine to the gluconeogenic activity in livers from hypoglycemic mice was investigated. The choice of these substances was based on the following facts: (1) alanine and glutamine are the most important gluconeogenic amino acid and the most abundant blood amino acid, respectively; (2) lactate and glycerol represent the major final metabolic products of muscle and adipose tissue, respectively; (3) they enter at different points of the gluconeogenesis giving the possibility of an evaluation of specific steps of this metabolic pathway.

In general, livers from the IIH group showed similar and lower LGP from glycerol and lactate, respectively, while higher $(P<0.05)$ LGP from alanine and glutamine was observed (Figure 4). Therefore, these experiments in the isolated liver help understand the best performance of the amino acids on the glycemia recovery (Figure 3 ).

The similar LGP from glycerol could be attributed to the fact that glycerol enters the gluconeogenic pathway after the step catalyzed by PEPCK $[31,32]$.

However, the step of entrance in the gluconeogenesis does not explain the liver response to lactate and alanine. Since lactate and alanine are converted to pyruvate, they should have a similar performance in terms of LGP. However, the LGP from alanine and lactate (Figure 4) in livers from IIH mouse was higher $(P<0.05)$ and lower $(P<0.05)$, respectively. These differences could be explained, partly at least, by the fact that the catabolism of lactate, deduced from pyruvate production (Table 1), was similar (NORMO versus IIH), while the catabolism of alanine, deduced from pyruvate, and lactate (Table 1) was higher $(P<0.05)$ in the IIH group.

Glutamine, which enters the gluconeogenic pathway at a more distal step compared with alanine or lactate, also showed higher $(P<0.05)$ LGP at the concentrations of 1.0, 12.0 , and $16.0 \mathrm{mM}$ (Figure 4) in the IIH group. However, the catabolism of glutamine inferred from urea production did not help explain the higher LGP from glutamine in livers of IIH mice.

Taken together, the results demonstrated that, despite insulin inhibiting gluconeogenesis, an increased gluconeogenic capacity from alanine and glutamine and maintained gluconeogenic capacity from glycerol and lactate were observed. These results are probably due to the fact that long-term IIH (180 min after insulin injection) triggers a counterregulatory response that maintains or even intensifies hepatic gluconeogenesis in mice, an animal model with high sensitivity to the hypoglycemic effect of insulin [33-35].

\section{Conclusions}

Our results demonstrate the superiority of oral glutamine to promote glycemia recovery in comparison with oral glucose opening perspectives for clinical studies to investigate the impact of oral administration of this amino acid during IIH.

\section{Conflict of Interests}

The authors declare that there is no conflict of interests in the current study.

\section{Acknowledgments}

The research is supported by CNPq (563870/2010-9), Araucaria Foundation, and PRONEX (24861/2012).

\section{References}

[1] S. Davis and M. D. Alonso, "Hypoglycemia as a barrier to glycemic control," Journal of Diabetes and Its Complications, vol. 18, no. 1, pp. 60-68, 2004.

[2] P. Singh, A. Jain, and G. Kaur, "Impact of hypoglycemia and diabetes on CNS: correlation of mitochondrial oxidative stress with DNA damage," Molecular and Cellular Biochemistry, vol. 260, no. 1, pp. 153-159, 2004.

[3] T. Hershey, N. Bhargava, M. Sadler, N. H. White, and S. Craft, "Conventional versus intensive diabetes therapy in children with type 1 diabetes: effects on memory and motor speed," Diabetes Care, vol. 22, no. 8, pp. 1318-1324, 1999.

[4] C. D. Agardh, I. Rosen, and E. Ryding, "Persistent vegetative state with high cerebral blood flow following profound hypoglycemia," Annals of Neurology, vol. 14, no. 4, pp. 482-486, 1983.

[5] H. M. Souza, N. S. Hell, G. Lopes, and R. B. Bazotte, "Effect of combined administration of counterregulatory hormones during insulin-induced hypoglycemia in rats: lipolysis mediated by a $\beta$-adrenergic mechanism contributes to hyperglycemia," Brazilian Journal of Medical and Biological Research, vol. 27, no. 12, pp. 2883-2887, 1994.

[6] G. Lopes, N. S. Hell, F. B. Lima, M. Vardanega, and R. B. Bazotte, "Responsiveness of glycogen catabolism to adrenergic agonists during insulin-induced hypoglycemia in rat livers," General Pharmacology, vol. 30, no. 4, pp. 593-599, 1998.

[7] H. M. Souza, N. S. Hell, G. Lopes, and R. B. Bazotte, "Synergistic effect of counterregulatory hormones during insulin-induced hypoglycemia in rats: participation of lipolysis and gluconeogenesis to hyperglycemia," Acta Pharmacologica Sinica, vol. 17, no. 5, pp. 455-459, 1996.

[8] R. F. Garcia, V. A. F. G. Gazola, H. C. Barrena et al., "Blood amino acids concentration during insulin induced hypoglycemia in rats: the role of alanine and glutamine in glucose recovery," Amino Acids, vol. 33, no. 1, pp. 151-155, 2007.

[9] H. C. Barrena, V. A. F. G. Gazola, M. M. D. P. Furlan, R. F. Garcia, H. M. de Souza, and R. B. Bazotte, "Ketogenesis evaluation in perfused liver of diabetic rats submitted to short-term insulininduced hypoglycemia," Cell Biochemistry and Function, vol. 27, no. 6, pp. 383-387, 2009.

[10] V. A. F. G. Gazola, R. F. Garcia, E. M. Hartmann et al., "Glycemia recovery with oral amino acid administration during experimental short-term insulin-induced hypoglycemia," Journal of Diabetes and its Complications, vol. 21, no. 5, pp. 320-325, 2007.

[11] R. Rodrigues, K. P. S. Feitosa, A. M. Felisberto Jr., H. C. Barrena, R. Curi, and R. B. Bazotte, "Comparative effects of short-term and long-term insulin-induced hypoglycemia on glucose production in the perfused livers of weaned rats," Pharmacological Reports, vol. 63, no. 5, pp. 1252-1257, 2011.

[12] F. P. M. Schiavon, V. A. F. G. Gazola, M. M. D. P. Furlan, H. C. Barrena, and R. B. Bazotte, "Paradoxical increase in liver ketogenesis during long-term insulin-induced hypoglycemia in diabetic rats," Experimental Biology and Medicine, vol. 236, no. 2, pp. 227-232, 2011.

[13] T. Y. Saleh and P. E. Cryer, "Alanine and terbutaline in the prevention of nocturnal hypoglycemia in IDDM," Diabetes Care, vol. 20, no. 8, pp. 1231-1236, 1997. 
[14] P. Kin, H. Parkin, I. A. MacDonald, C. Barber, and R. B. Tattersall, "The effect of intravenous lactate on cerebral function during hypoglycemia," Diabetic Medical, vol. 14, pp. 19-28, 1997.

[15] S. W. Suh, K. Aoyama, Y. Matsomori, J. Liu, and R. A. Swanson, "Pyruvate administered after severe hypoglycemia reduces neuronal death and cognitive impairment," Diabetes, vol. 54, no. 5, pp. 1452-1458, 2005.

[16] S. Obici, T. M. Tavoni, H. C. Barrena, R. Curi, and R. B. Bazotte, "Time sequence of the intensification of the liver glucose production induced by high-fat diet in mice," Cell Biochemistry and Function, vol. 30, pp. 335-359, 2012.

[17] N. Tobar, A. G. Oliveira, D. Guadagnini et al., "Diacerhein improves glucose tolerance and insulin sensitivity in mice on a high-fat diet," Endocrinology, vol. 152, no. 11, pp. 4080-4093, 2011.

[18] K. S. Haida, G. Bertachini, T. Tavoni, M. Guilhermetti, M. R. Loures, and R. B. Bazotte, "Infliximab treatment prevents hyperglycemia and the intensification of hepatic gluconeogenesis in an animal model of high fat diet-induced liver glucose overproduction," Brazilian Archives of Biology and Technology, vol. 55, pp. 389-394, 2012.

[19] L. H. Guerreiro, D. Da Silva, M. Sola-Penna, D. M. Mizurini, and L. M. Lima, "Amylin induces hypoglycemia in mice," Anais da Academia Brasileira de Ciências, vol. 85, pp. 349-354, 2013.

[20] I. Gutmann and W. Wahlefeld, "L-(+)-Lactate. Determination with lactate dehydrogenase and NAD," in Methods of Enzymatic Analysis, H. U. Bergmeyer, Ed., pp. 1464-1472, Academic Press, New York, NY, USA, 1974.

[21] R. Czok and W. Lamprecht, "Pyruvate, phosphoenolpyruvate and D-glycerate-2-phosphate," in Methods of Enzymatic Analysis, H. U. Bergmeyer, Ed., pp. 1446-1448, Academic Press, New York, NY, USA, 1974.

[22] I. Gutmann and H. U. Bergmeyer, "Determination of urea, indicator reaction with phenol and hypochorite," in Methods of Enzymatic AnalysisVerlag, H. U. Bergmeyer, Ed., pp. 1790-1798, Academic Press, New York, NY, USA, 1974.

[23] M. Ader and R. N. Bergman, "Peripheral effects of insulin dominate suppression of fasting hepatic glucose production," American Journal of Physiology, vol. 258, no. 6, pp. E1020-E1032, 1990.

[24] M. A. Osundiji, M. L. Godes, M. L. Evans, and N. N. Danial, "BAD modulates counterregulatory responses to hypoglycemia and protective glucoprivic feeding," PLoS ONE, vol. 6, no. 12, Article ID e28016, 2011.

[25] H. Shamoon, R. Hendler, and R. S. Sherwin, "Synergistic interactions among antiinsulin hormones in the pathogenesis of stress hyperglycemia in humans," Journal of Clinical Endocrinology and Metabolism, vol. 52, no. 6, pp. 1235-1241, 1981.

[26] C. Moore and M. Woollard, "Dextrose $10 \%$ or $50 \%$ in the treatment of hypoglycaemia out of hospital? A randomised controlled trial," Emergency Medicine Journal, vol. 22, no. 7, pp. 512-515, 2005.

[27] R. F. Garcia, V. A. F. G. Gazola, E. M. Hartmann et al., "Oral glutamine dipeptide promotes acute glycemia recovery in rats submitted to long-term insulin induced hypoglycemia," Latin American Journal of Pharmacy, vol. 27, no. 2, pp. 229-234, 2008.

[28] W. W. Souba, "Glutamine: a key substrate for the splanchnic bed," Annual Review of Nutrition, vol. 11, pp. 285-308, 1991.

[29] P. J. Hanson and D. S. Parsons, "Metabolism and transport of glutamine and glucose in vascularly perfused small intestine rat," Biochemical Journal, vol. 166, no. 3, pp. 509-519, 1977.
[30] C. Boutry, H. Matsumoto, C. Bos et al., "Decreased glutamate, glutamine and citrulline concentrations in plasma and muscle in endotoxemia cannot be reversed by glutamate or glutamine supplementation: a primary intestinal defect?" Amino Acids, pp. 1-14, 2012.

[31] S. C. Burgess, N. Hausler, M. Merritt et al., "Impaired tricarboxylic acid cycle activity in mouse livers lacking cytosolic phosphoenolpyruvate carboxykinase," Journal of Biological Chemistry, vol. 279, no. 47, pp. 48941-48949, 2004.

[32] P. Jiao, B. Feng, and H. Xu, "Mapping MKP-3/FOXO1 interaction and evaluating the effect on gluconeogenesis," PLoS ONE, vol. 7, no. 7, Article ID e41168.

[33] F. Märki and W. Albrecht, "Biological activity of synthetic human insulin," Diabetologia, vol. 13, no. 4, pp. 293-295, 1977.

[34] V. K. Bhargava and S. Balakrishnan, "Role of nitric oxide on insulin induced seizures in mice," Indian Journal of Physiology and Pharmacology, vol. 43, no. 3, pp. 373-377, 1999.

[35] L. J. King, O. H. Lowry, J. V. Passonneau, and V. Venson, "Effects of convulsants on energy reserves in the cerebral cortex," Journal of Neurochemistry, vol. 14, no. 6, pp. 599-611, 1967. 


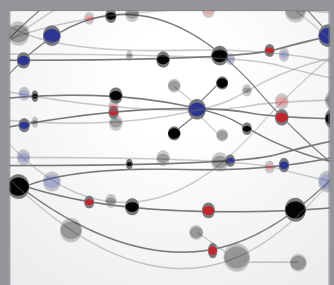

The Scientific World Journal
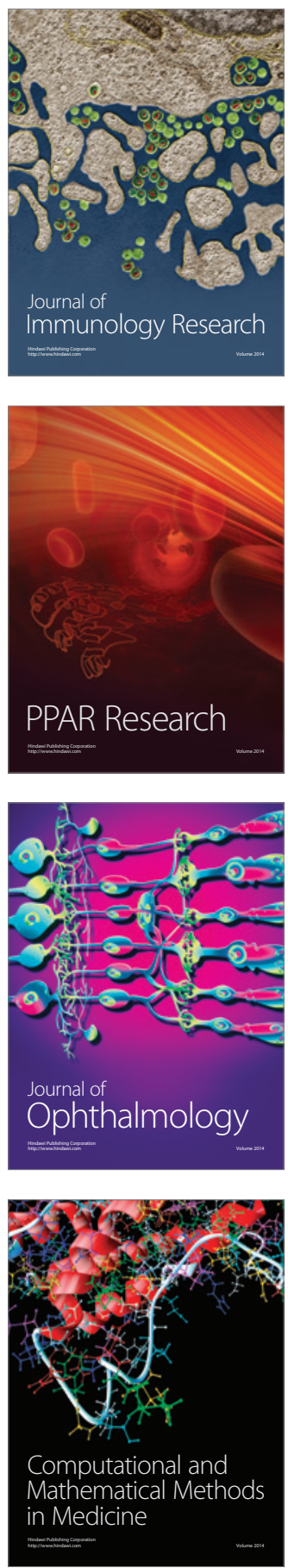

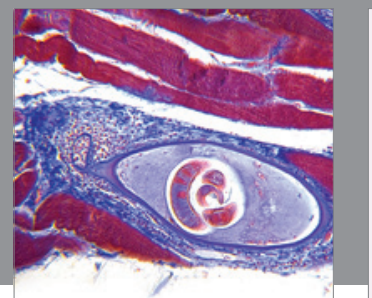

Gastroenterology

Research and Practice
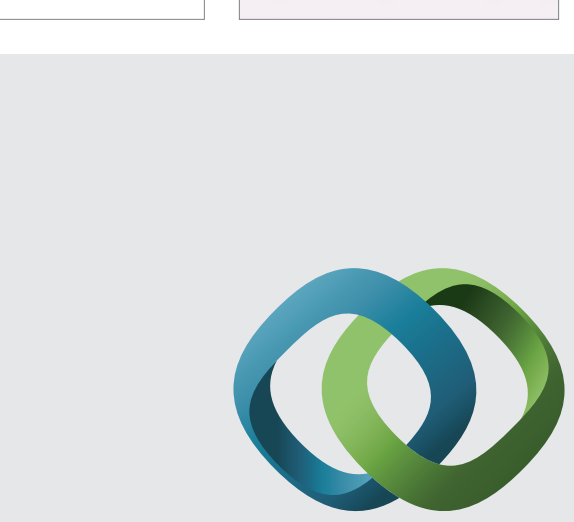

\section{Hindawi}

Submit your manuscripts at

http://www.hindawi.com
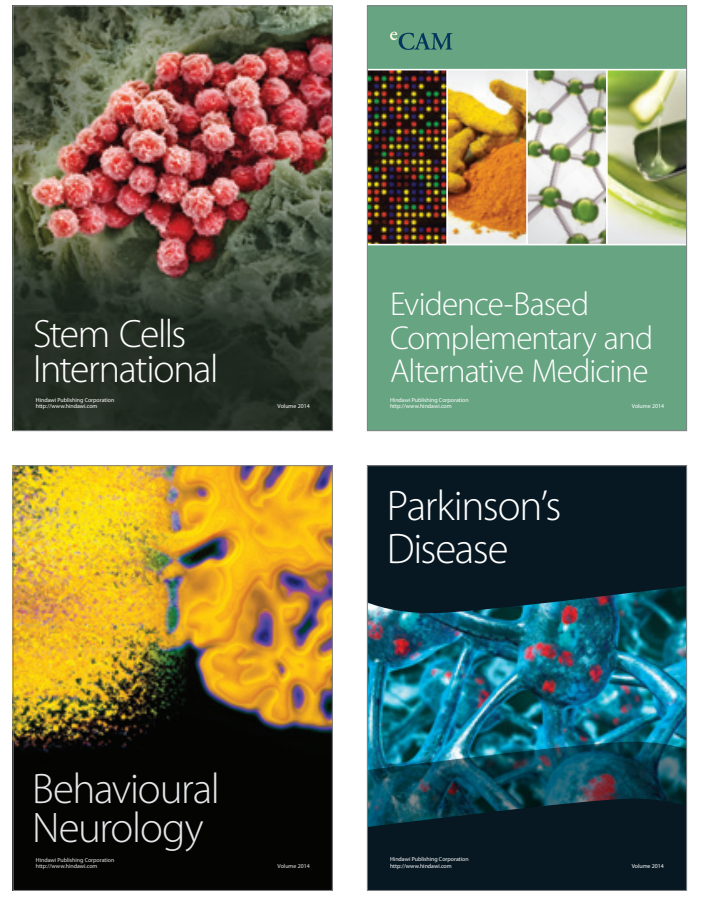
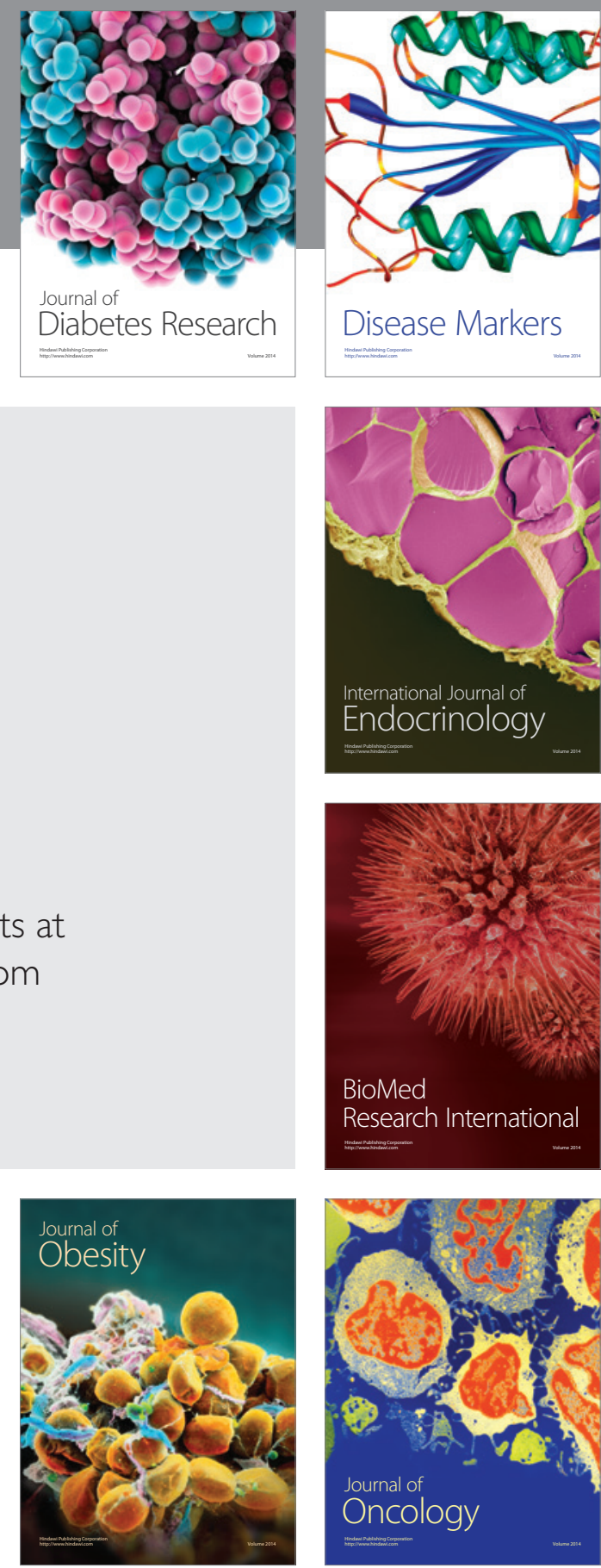

Disease Markers
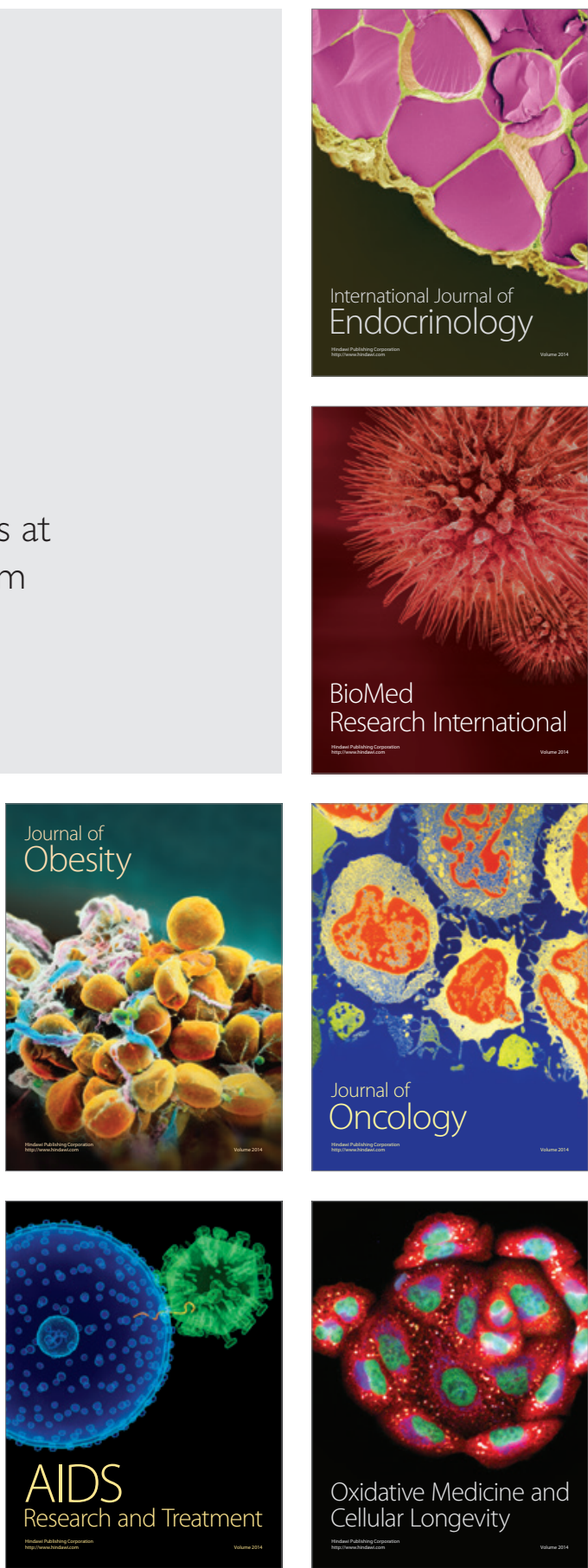